\title{
ФОРМИРОВАНИЕ КОНСТРУКТИВНЫХ УМЕНИЙ ДЕТЕЙ СТАРШЕГО ДОШКОЛЬНОГО ВОЗРАСТА ПОСРЕДСТВОМ ЛЕГО-КОНСТРУИРОВАНИЯ И РОБОТОТЕХНИКИ
}

Тимофеева Н.И.

студентка

Научный руководитель: Попова Л.В.

к.П.н., доцент

Северо-Восточный федеральный университет им. М.К. Аммосова, г. Якутск, Россия

\begin{abstract}
Аннотация: В этой статье авторы рассматривают использование Легоконструирования и робототехники для реализации процесса формирования конструктивных умений у детей старшего дошкольного возраста. Использование конструкторов LEGO WeDo в образовательном процессе с детьми формирует их конструктивные умения. Статья имеет практикоориентированный характер. В ней представлен проект кружка по Легоконструированию и робототехники «Лего-роботы» с включением регионального компонента.
\end{abstract}

Ключевые слова: конструктивные умения, робототехника, конструктор LEGO, образовательная робототехника, региональный компонент.

\section{THE FORMATION OF CONSTRUCTIVE SKILLS OF PRESCHOOL CHILDREN THROUGH LEGO CONSTRUCTION AND ROBOTICS}

\author{
N.I. Timofeeva \\ a student \\ Scientific adviser L.V. Popova
}

\begin{abstract}
In this article, the authors view the use of Lego construction and robotics to implement the process of forming constructive skills of preschool children. The use of LEGO WeDo constructors in the educational process forms children's constructive skills. The article is practice-oriented.

It presents a project of the Lego-construction and robotics circle "Lego-robots" including a regional component.
\end{abstract}




\section{ВСЕРОССИЙСКИЙ ИССЛЕДОВАТЕЛЬСКИЙ ФОРУМ

Key words: constructive skills, robotics, LEGO constructor, educational robotics, regional component.

Практика педагогов современных ДОО показала, что сегодня робототехника очень востребована именно как средство активизации формирования конструктивных умений. Это возможно благодаря тому, что эта технология способствует совершенствованию зрительного восприятия, образного мышления, памяти, привитию умелости ручных действий, развивает чувство прекрасного. Такое благотворное ее влияние позволяет считать данную проблему актуальной и значимой.

В дошкольном образовании в настоящее время особое внимание уделено Лего-конструированию и робототехнике. Конструктивная деятельность В Федеральном государственном образовательном стандарте дошкольного образования и образовательных программах дошкольных образовательных организаций является одной из основных. Лего-конструирование и робототехника нацелены на формировании первоначальных представлений о мире техники, устройстве механизмов и машин, развитие способностей научно-технического моделирования, навыков исследовательской деятельности и творчества [1, с. 41].

Робототехника - это естественная и интересная для каждого ребенка форма игровой деятельности и познавательной активности, в которой он проявляет себя через непроизвольные манипуляции, создание различных построек и поделок непосредственное выражение своего внутреннего состояния, реализует различные непосредственные двигательные и игровые потребности [2, с. 19].

По мнению Ю.Г. Гуревич, применение робототехники детьми старшего дошкольного возраста - современный вид проектной технологии, очень привлекательный для детей 5-6 лет. Одним из важных средств развития творческих способностей здесь является использование в образовательном процессе творческих заданий, что может преобразить традиционные занятия, рационализировав детский интерес, оптимизировав процессы понимания и запоминания материала по основным направлениям дошкольного образования, а главное, подняв на более высокий уровень интерес детей к самостоятельной деятельности [3, с. 181].

Актуальность данной проблемы определяет необходимость проведения системы мероприятий, направленных на формирование конструктивных умений детей дошкольного возраста. 
Для этого нами было проведено исследование для выявления уровня знаний и умений по Лего-конструированию и робототехнике на основе методик Е.В. Фешиной и Т.В. Федоровой в старшей группе МБДОУ Д/с №85 «Золотой ключик» городского округа «город Якутск». В эксперименте участвовало 20 детей: экспериментальная и контрольная группы по 10 детей.

При анализе данных констатирующего этапа нами были получены следующие данные: в экспериментальной группе $30 \%$ детей имеют высокий уровень, $40 \%$ средний уровень и $30 \%$ низкий уровень. В контрольной группе: высокий уровень $-20 \%$, средний уровень $-40 \%$, низкий $40 \%$.

Дети с помощью простых схем создавали конструкцию, при этом прибегают к помощи взрослого. Самостоятельно могут подбирать детали по форме, цвету и величине. При работе со сложными схемами затрудняются, четко не умеют объяснять свой замысел, описать ожидаемый результат, анализировать. Также кроме этого не могут назвать названия некоторых деталей конструктора Лего.

Итоги обследования показали, что у детей в экспериментальной и контрольной группах разные уровни сформированности конструктивных умений. Диагностика формирования конструктивных умений помогло выяснить индивидуальные особенности развития умений каждого ребенка, a также удалось получить разностороннюю информацию о состоянии сформированности конструктивных умений у детей старшего дошкольного возраста для выбора подходящих содержания и методов обучения.

Эти результаты доказывают необходимость проведения формирующей работы в экспериментальной группе. Исходя из этого нами был разработан проект кружка по Лего-конструированию и робототехники «Лего-роботы».

При внедрении проекта использовали образовательный конструктор LEGO Education WeDo 9580. Для успешной работы кружка по данному направлению создали ряд условий:

- разработали проект и перспективный план с региональным компонентом;

- организовали в группе центр Лего-конструирования и робототехники, центр «Моя родная Якутия»;

- приобрели конструкторы различной модификации (от простых кубиков, до конструкторов с программным обеспечением); 


\section{ВСЕРОССИЙСКИЙ ИССЛЕДОВАТЕЛЬСКИЙ ФОРУМ

- организовали занятия кружка с обязательным включением регионального компонента, по разработанному алгоритму работы с конструкторским материалом;

- разработали пооперационные карты (схемы) к новым конструкциям по региональному компоненту.

Основываясь на знания и умения детей, которые сформированы при работе с образовательным робототехническим модулем ТР-0152 (предварительный уровень), была поставлена новая задача: формирование конструктивных умений, мышления, самостоятельности детей старшего дошкольного возраста в конструктивно-модельной деятельности.

Для развития кругозора и знаний о родном крае включили темы по региональному компоненту. Нами были предложены следующие виды построек: талкы (коже мялка), охотничье снаряжение - капкан, лук самострел, персонажи якутской сказки «Старушка Таал-Таал», настольная игра «Сонор», персонажи Олоцхо, кулунчук (жеребенок), музыкальный инструмент - хомус, ытык (мутовка).

В ходе проведения кружка «Лего-роботы» мы усложняли задания и схемы постройки. Во время работы с конструктором дети работали по подгруппам и индивидуально. Детей радовало то, что всегда учитываются их интересы, инициатива. На кружковых занятиях, в совместной деятельности со взрослым дети приобретали основные конструктивные умения, а затем изменяя переносили их в самостоятельные игры.

Конструктивная деятельность для детей стала интересной, так как дала возможность сделать открытие, придумать и создать что-то свое новое, оригинальное. Дети научились конструировать сложные конструкции. Такое обучение дает возможность продвигаться вперед, учитывая темп ребенка, которое приводит его к желанию познавать новое, решать сложные задачи.

Таким образом, мы считаем, что работа с образовательным конструктором LEGO Education WeDo 9580 дает возможность детям в дальнейшем развивать и усовершенствовать приобретенные конструктивные умения. Из этого следует сделать вывод, что для увлеченных конструкторской деятельностью детей эффективными могут стать активные способы взаимодействия с миром техники: создание условий для освоения элементов науки и техники (занимательной инженерии, механики, физики, роботостроения) в форме кружка. 


\section{Список литературы}

1. Конструирование роботов с детьми. Методические рекомендации для организации занятий: образовательный робототехнический модуль (предварительный уровень): 5-8 лет. ФГОС ДО/Д.А.Каширин, А.А.Каширина. - М.: Издательство «Экзамен», 2015. - 120 с.

2. Барташникова, И.Я. Учись, играя: Тренировка интеллекта. Игра и тесты для детей 5-7 лет / И.Я. Барташникова, А.А. Барташников. - СПб.: Питер, 2018. - 412 с.

3. Гуревич, Ю.Г. Психологические особенности творческой деятельности: Учеб. пособие / Ю.Г. Гуревич, С.В. Кошелева. - Иркутск: Издво Иркутского университета, 2018. - 231 с. 